\title{
Maternal Mortality in the Obstetrics and Gynecology Service of Regional Hospital Center of Ouahigouya: Epidemiological, Etiological Aspects and Contributing Factors-About 151 Cases Collected in Three Years from 1st January 2013 to 31 December 2015
}

\author{
Issa Ouedraogo 1,2, Sansan Rodrigue Sib 1,2, Sibraogo Kiemtore ${ }^{2,3}$, Yobi Sawadogo 2,3, \\ Dantola Paul Kain 2,3, Hyacinthe Zamané2,3, Adama Ouattara ${ }^{2,3}$, Alexandre Goumbri1, \\ Sidbéwenné Yacinthe Kabore ${ }^{4}$, Ali Ouedraogo ${ }^{2,3}$, Blandine Bonané-Thiéba ${ }^{2,3}$ \\ ${ }^{1}$ Department of Obstetrics and Gynecology, Teaching Hospital in Ouahigouya, Ouahigouya, Burkina Faso \\ ${ }^{2}$ Unity of Training and Research in Health Sciences (UFR/SDS), University of Ouagadougou, Ouagadougou, Burkina Faso \\ ${ }^{3}$ Department of Obstetrics and Gynecology, Yalgado Ouedraogo Teaching Hospital in Ouagadougou, Ouagadougou, Burkina Faso \\ ${ }^{4}$ Department of Obstetrics and Gynecology, Teaching Hospital in Tenkodogo, Tenkodogo, Burkina Faso \\ Email: oued_issa2002@yahoo.fr
}

How to cite this paper: Ouedraogo, I., Sib, S.R., Kiemtore, S., Sawadogo, Y., Kain, D.P., Zamané, H., Ouattara, A., Goumbri, A., Kabore, S.Y., Ouedraogo, A. and Bonané-Thiéba, B. (2017) Maternal Mortality in the Obstetrics and Gynecology Service of Regional Hospital Center of Ouahigouya: Epidemiological, Etiological Aspects and Contributing Factors-About 151 Cases Collected in Three Years from 1st January 2013 to 31 December 2015. Open Journal of Obstetrics and Gynecology, 7, 447-454. https://doi.org/10.4236/ojog.2017.74046

Received: March 6, 2017

Accepted: April 23, 2017

Published: April 26, 2017

Copyright $\odot 2017$ by authors and Scientific Research Publishing Inc. This work is licensed under the Creative Commons Attribution International License (CC BY 4.0). http://creativecommons.org/licenses/by/4.0/

\section{Abstract}

The objective of our study was to study the epidemiological, etiological and contributory factors of maternal deaths in the obstetrics and gynecology department of the regional hospital center (RHC) of Ouahigouya from 2013 to 2015. We carried out a descriptive and analytical study on maternal deaths in maternity of the RHC of Ouahigouya, including all patients who died in the obstetrics and gynecology department of the RHC of Ouahigouya from 1 January 2013 to 31 December 2015, which meets WHO's definition of maternal death. We recorded 151 maternal deaths and 5481 live births, a maternal mortality ratio of 2755 per 100,000 live births. The most affected women were women aged 20 - 24 years (27.8\%), multiparous (25.5\%), married women (88.7\%) and those without income-generating activities (85.4\%). The main causes of death from direct obstetrical complications were hemorrhage (38.3\%), infections (21.5\%), abortions (16.8\%) and complications of hypertension disorders $(15.8 \%)$ and for indirect obstetrical complications, malaria (36.6\%), anemia (29.5\%), and HIV/AIDS (9.1\%). Contributing factors to maternal deaths prior to admission were delay in referral (33.3\%) and delay in transfer (31.5\%) and delay in admission (32.8\%) and delay in diagnosis (23.4). From our study, it appears elsewhere as well as that most maternal deaths are preventable, hence the need for coordinated actions to effectively fight against 
maternal mortality.

\section{Keywords}

Maternal Mortality, Epidemiological Aspects, Etiologies, Contributing Factors

\section{Introduction}

Maternal mortality is still a public health worry in low income countries. Per day in the world, 800 women die during pregnancy or delivery. Most of them (99\%) are in low income countries [1]. In 2013 in the world, 289,000 women died by pregnancies or deliveries complications or in the following days.

The highest maternal mortality in the world is noted in Sub-Saharan Africa: 510 deaths per 100,000 live births. In Burkina Faso, it estimated to 300 per 100,000 live births [1].

Maternal mortality reduction is a priority objective in all countries, especially in low income countries for one quarter of century [2].

Improvement of maternal health was one of the eight millenary development objectives adopted by international community which aimed to reduce the maternal mortality of three quarters between 1990 and 2015. The objective was not reached because 25 years after its adoption, that rate is reduced but of $45 \%$ [3]; the maternal mortality is decreased but remains high of 303,000 in 2015 [4].

The contributing factors leading to maternal deaths are: carelessness of health services, maladjusted therapeutics, lack of blood transfusion, patient's recklessness, lack of medical management of abortions, diagnostic mistakes, difficulties of transportation [5].

The northern region housing the RHC of Ouahigouya is part of the areas where the maternal mortality ratio is high in the country [6].

Whatever well conduced, policies aiming to reduce the maternal mortality suffer of big hiatus in practice and show clearly the necessity to improve these strategies. Numerous studies have been carried out on maternal mortality, but until now we have no specific studies on the northern region and particularly at the level of the RHC of Ouahigouya, especially after the implementation of the innovative interventions for the reduction of this maternal mortality (audits of maternal deaths).

The aim of our work is to study epidemiological, etiological aspects and contributing factors of maternal mortality in obstetrics and gynecology service of regional hospital center of Ouahigouya.

\section{Patients and Methods}

The study was performed in the obstetrics and gynecology service of RHC of Ouahigouya.

The RHC of Ouahigouya is the referral center of six sanitary districts of the North Region which are: Ouahigouya, Titao, Thiou, Seguenega, Gourcy and 
Yako. Its population zone of cover is estimated of 1,306,619 inhabitants. We conducted a cross-sectional study for descriptive and analytical purposes including a retrospective data collection during a period of 3 years, from $1^{\text {st }}$ January 2013 to $31^{\text {st }}$ December 2015.

Our study is based on maternal deaths cases meeting WHO definition recorded in the service of obstetrics and gynecology of the RHC of Ouahigouya during our period study. Then, the WHO defines maternal mortality as: the death of a woman while pregnant or within forty two days of termination, irrespective of duration or site of pregnancy, from any cause related to or aggravated by the pregnancy or its management but not from accidental or incidental causes.

We're not included in the study the patients whom clinical folder was unusable.

The variables of study were: socio-demographic characteristic (age, occupation, marital status, residency) clinical characteristic (mode of admission, medical histories, the time of death) the management, the causes of death and contributing factors.

Using a questionnaire pretested which contained the patient identity, the medical history, pregnancy antenatal clinic, clinical signs, the management, the causes of death and the contributing factors.

The data were collected using patient's clinical folder, death register, births register, hospitalization register and delivery register during the study period at maternity of RHC of Ouahigouya.

Data were collected and analyzed using Epi info 3.5.4 version.

Results have been presented in percentage for qualitative variables and means and standard deviation for quantitative variables.

\section{Results}

\subsection{Maternal Mortality Ratio}

During the study period, we recorded 14,273 admissions out of which, 151 maternal deaths giving a rate of $10.6 \%$. The maternal mortality ratio was 2755 per 100,000 live births (151 on 5481 live births).

\subsection{Socio-Demographic Characteristics (Table 1)}

The mean age of patients was $26.2 \pm 7$ years with extremes of 15 years and 41 years. The women died under 25 years old represented $47.7 \%$ of cases. The mean parity was $2.85 \pm 2.7$ and the biggest parity observed was 11 . The multiparous women were represented in $25.5 \%$ of cases. The women without income salary activities (wife house, students) occupied $85.4 \%$ and $88.7 \%$ were marital status (married or cohabiting).

\subsection{Clinical Characteristics}

In our study, 143 patients (96\%) were referred, 13 (9.5\%) had at least 4 prenatal consultations recommended by WHO. One hundred and twenty three patients (81.5\%) had no medical history, 7 patients $(4.6 \%)$ were positives in human im- 
Table 1. Distribution of patients by socio-demographic characteristics $(\mathrm{N}=151)$.

\begin{tabular}{ccc}
\hline Parameters & Number & Percentage \\
\hline Age (years) & 30 & 20 \\
$\leq 19$ & 42 & 27.8 \\
$20-24$ & 25 & 16.5 \\
$25-29$ & 21 & 14 \\
$30-34$ & 24 & 16 \\
$35-39$ & 9 & 5.7 \\
$\leq 40$ & & \\
Parity & 37 & 24.2 \\
Nulliparous & 30 & 20.1 \\
Primiparous & 30 & 20.1 \\
Pauciparous & 39 & 25.5 \\
Multiparous & 15 & 10.1 \\
Large multiparous & & \\
Profession & 122 & 81 \\
Housewives & 15 & 10 \\
Shopkeepers & 6 & 4 \\
Officials & 8 & 5 \\
Students & & \\
\hline
\end{tabular}

Table 2. Distribution of maternal deaths by duration of hospitalization $(\mathrm{N}=147)$.

\begin{tabular}{ccc}
\hline Duration of hospitalization & Number & Percentage (\%) \\
\hline$<1$ hour & 7 & 4.7 \\
$1-24$ hours & 77 & 5.4 \\
$25-72$ hours & 32 & 21.7 \\
$3-6$ days & 10 & 6.8 \\
$\geq 6$ days & 21 & 14.4 \\
Total & 147 & 100 \\
\hline
\end{tabular}

munodeficiency virus, and 2 patients (1.3\%) had high blood pressure. These deaths occurred during pregnancy in 54 cases $(35.7 \%)$, in the postpartum in 77 cases (51\%) and in the post abortum in 17 cases (11.3\%).

\subsection{Duration of Hospitalization}

The duration was varied, from dead at admission to 27 days and the women dead within first 24 hours represented $57.1 \%$ as Table 2 shows.

\subsection{Causes of Death}

As Table 3 shows it, the direct causes involved 107 patients (71\%): 51 cases of hemorrhage (38.3\%), 23 cases of infections (21.5\%), 18 cases of abortions (16.8\%), hypertensions disorders 17 cases (15.8\%), 8 cases of dystocia (7.8\%).

About indirect causes (Table 4), it involved 44 patients (29\%): 16 from malaria (36.6\%), 13 cases of anemia (29.5\%), 4 cases of HIV/AIDS (9.1\%). 
Table 3. Distribution of maternal deaths by direct obstetric causes $(\mathrm{N}=107)$.

\begin{tabular}{|c|c|c|}
\hline Direct obstétric causes & Number & Percentage (\%) \\
\hline -Haemorrages & 41 & 38.3 \\
\hline postpartum haemorrhage & 20 & 48.8 \\
\hline Uterine Rupture & 7 & 17 \\
\hline Placentalabruptio & 4 & 9.7 \\
\hline Placenta praevie & 7 & 16.5 \\
\hline Ectopicpregnancy & 3 & 8 \\
\hline -Infections & 23 & 21.5 \\
\hline Septicemia & 6 & 26 \\
\hline Endometritis & 8 & 34.7 \\
\hline Urogenital & 3 & 13 \\
\hline Wound suppuration & 4 & 17.7 \\
\hline Chorioamniotitis & 1 & 4.3 \\
\hline Pelvipéritonitis & 1 & 4.3 \\
\hline -Abortions & 18 & 16.8 \\
\hline Infections after clandestine induced abortion (CIA) & 6 & 33.3 \\
\hline Hemorrhage by CIA & 5 & 27.7 \\
\hline Hemorrhage by spontaneous abortion & 5 & 27.7 \\
\hline Infection after spontaneous abortion & 2 & 11.3 \\
\hline -Hypertension disorders & 17 & 15.8 \\
\hline Eclampsia & 8 & 47 \\
\hline Severe preclampsa & 7 & 41.1 \\
\hline post partum hypertension & 2 & 11.9 \\
\hline -Dystocia & 8 & 7.6 \\
\hline Total & 107 & 100 \\
\hline
\end{tabular}

Table 4. Distribution of maternal deaths by indirect obstetric causes $(\mathrm{N}=44)$.

\begin{tabular}{ccc}
\hline Indirect obstetric causes & Number & Percentage (\%) \\
\hline Chronic anemia & 13 & 29.5 \\
Malaria & 16 & 36.6 \\
Sickle cell disease & 3 & 6.8 \\
Meningitis & 2 & 4.5 \\
Cardiopathy & 2 & 4.5 \\
HIV/AIDS & 4 & 9.1 \\
Kidney failure & 1 & 2.2 \\
Other & 3 & 6.8 \\
Total & 44 & 100 \\
\hline
\end{tabular}

\subsection{Contributive Factors to Maternal Deaths}

\section{-Before admission}

Contributing factors were represented by delay to reference $(33.3 \%)$, delay of consultation (31.5\%) and the insufficiency of medical materials or instruments 
(22.9\%).

\section{-After admission}

Contributing factors were represented by the delay of management $(32.8 \%)$, insufficiency of financial means (26\%), delay of diagnostic (23.4\%) and the lack of blood transfusion products (17.8\%).

\section{Discussion}

\subsection{Limits and Bias}

Being that the study was retrospective, we could not get all of information because some of patient folders were filled incorrectly. So, we were not able to determine the other maternal deaths cases out of our service.

\subsection{Ampleness of Maternal Mortality}

In Burkina Faso, maternal mortality ratio has moved from 484 per 100,000 live births in 1998 to 341 per 100,000 live births in 2010 [7]. Despite that decrease, numbers remain high. Our study has based on hospital data and the ratio was 2755 per 100,000 live births. That high frequency is comparable to those found by others authors working in the same situations: 2029 per 100,000 live births in Ivory Coast [8] and 2031 per 100,000 live births in Mali [9]. It is less elevated in some regions: Sudan 442 per 100,000 live births [10] and 92.6 per 100,000 live births in Algeria [11].

The high rate is due to the fact that our service is a referral maternity and receives patients increase by the concentration of pathologies phenomenon and late transfer.

\subsection{Causes of Deaths}

In our study, the direct obstetrical causes represented $71 \%$ were dominated by hemorrhages (38.3\%), infections (21.5\%) and abortions (16.8\%). Hemorrhage was often the first cause in low income countries [12] [13] than developed countries. It was represented to $38.3 \%$ of all causes in our series. That rate was similar to that found by GARBA in Niger which was 37.5\% [14] and that of TRAORE in Mali [9], 38.4\%. But it was slightly higher than that of NAYAMA [15] which was $28.8 \%$. Among hemorrhages causes, post partum hemorrhage was in first place with $48.8 \%$ followed by uterine rupture $(17 \%)$ and placenta praevia $(16.5 \%)$. The permanent scarcity of blood products, bad situations and long transfer delay, installation of a hemorrhagic shock and/or coagulopathy are the main insufficiencies at the origin of deaths.

The indirect obstetrical complications were $29 \%$ of deaths causes and were dominated by malaria (36.6\%), anemia (29.5\%), HIV/AIDS (9.1\%). In Niger, GARBA [14] has found that anemia was the first of indirect causes with $42.2 \%$ followed by malaria (12.5\%) and HIV/AIDS (3.1\%). That difference lay due to the difficulties of get a right diagnosis linked to the limited capacity of paraclinic in our countries. 


\subsection{Contributing Factors to Maternal Deaths}

Contributing factors have been essentially the late of transfer, of consultation and of management and the lack of blood transfusion products and financial means. Financial worries were identified in $26 \%$ of cases among associated factors. Our findings are widely inferior to those found by BOHOUSSOU and coll. [8] who estimated that financial charge of woman and her family were engaged in the late of management. That difference may explain by the establishing by the state since 2006 of subvention of obstetrical and neonatal emergency care which has positively impacted on this contributing factor. The lack of blood transfusion products has been identified in $17.8 \%$. This rate is than that of LEKE [16] in a study performed in the central hospital of Yaounde who found $7.69 \%$ of factors linked to lack of blood transfusion products.

Crucial lack of blood transfusion products in our hospitals lead to difficult adequate management of some of pathologies (hemorrhages, anemia) so that health staff sometimes attend impotently to dramatic situation that occurs.

\section{Conclusions}

Our study has shown a gradual decrease of maternal deaths ratio over years. However, woman profile that dies is that of young woman, house wife, multiparous and without salary activity. As for etiology: hemorrhage, infections, complications of abortion and hypertension disorders remain the main causes of death.

If most of deaths are avoidable, the larger reduction should guide policies toward an improvement of contraceptive cover, better available in blood transfusion products, and an improvement of quality of antenatal consultations as well as a better prevention of infections in our clinical practice.

\section{References}

[1] WHO, UNICEF, UNFPA and World Bank Estimates, Trends in Maternal Mortality: 1990 to $2013,2014$.

http://www.who.int/reproductivehealth/publications/monitoring/maternal-mortalit $\mathrm{y}-2013 / \mathrm{en} /$

[2] UNICEF. Initial Analysis of Maternal Neonatal and Child Health in the French Muskoku Fund in Burkina Faso: Final Report. December 2012: 17.

[3] WHO. Maternal Mortality in 2005: Estimates by WHO, UNICEF, UNFPA and the World Bank. Geneva, Switzerland. WHO 2007: 54.

[4] WHO, UNICEF, MDG. Report of November 2015: 9.

[5] WHO, Reduce Maternal Mortality. Joint Statement WHO/UNFPA/UNICEF/World Bank 1999. Geneva: 45.

[6] Ministry of Health, 2014 Health Indicators Scoreboard-Burkina Faso, 2015: 99.

[7] National Institute of Statistics and Demography (INSD) and ICF International: Demographic and Health Survey and Multiple Indicators of Burkina Faso 2010, 2012: 211.

[8] Bohoussou, K.P.E., Guie, P., Oyelade, M., N’Guessan, E., Anongba, S. and Coulibaly, T. (2012) Evolution of Maternal Mortality at the Maternity of University Hospit- 
al Center of Treichville in Abidjan from 2005 to 2009. Journal of SAGO, 13, 6-10.

[9] Traore, B., Thera, T.A., Kokaina, C., Beye, S.A., Mounkoro, N., Teguete, I., Dolo, A. (2010) Maternal Mortality in the Obstetrics and Gynecology Department of the Regional Hospital Center of Ségou in Mali, Retrospective Study of 138 Cases. Le Mali Medical, 25, 42-47.

[10] Elhassan, E.M., Mirghani, O.A. and Adam, I. (2009) High Maternal Mortality and Stillbirth in the Wad Medani Hospital, Central Sudan, 2003-2007. Tropical Doctor, 39, 238-239. https://doi.org/10.1258/td.2009.090005

[11] Ouchtati, M., Mezhoud, S. and Rahmoun, F.C. (2009) Millennium Development Goals and Maternal Mortality: Confluence and Cross-Tabulation of All Inequalities. Workbooks and Francophone Research, 19, 167-170.

[12] Mayi-Tsongas, Ndombi I., Oksana I., et al. (2008) Maternal Mortality in Libreville (Gabon): State of Play and Challenges to Be Addressed in 2006. Workbooks and Francophone Research/Health, 18, 193-197.

[13] Jacques, S., Edgard-Marius, O. and Bruno, D. (2006) Maternal Deaths Audit in Four Benin Referral Hospital Quality Emergency Care Causes and Contributing Factors. African Journal of Reproductive Health, 10, 28-40.

https://doi.org/10.2307/30032469

[14] Garba, R.M., Nayama, M., Cisse Akilou, A., Idi, N., Oumara, M. and Guede, S. (2012) Maternal Mortality at the Reference Maternity Issaka Gozobi of Niamey. Journal of SAGO, 13, 12-17.

[15] Nayama, M., Djibo-Koba, A., Garba, M., Idi, N., Marafa, A., Diallo, F.Z., Toure, A., Djibril, B. and Illa-Souley, B. (2006) Maternal Mortality at Maternal Level in Niger: Retrospective Study of 104 Cases. Medicine of Black Africa, 53, 687-693.

[16] Leke, R. (2004) Postgraduates Research Training in Reproductive Health 2004. Santé Yaoundép, 4-17.

\section{Submit or recommend next manuscript to SCIRP and we will provide best service for you:}

Accepting pre-submission inquiries through Email, Facebook, LinkedIn, Twitter, etc. A wide selection of journals (inclusive of 9 subjects, more than 200 journals) Providing 24-hour high-quality service User-friendly online submission system Fair and swift peer-review system Efficient typesetting and proofreading procedure Display of the result of downloads and visits, as well as the number of cited articles Maximum dissemination of your research work

Submit your manuscript at: http://papersubmission.scirp.org/ Or contact ojog@scirp.org 